\title{
Home range and density of three sympatric felids in the Southern Atlantic Forest, Brazil
}

\author{
C. B. Kasper ${ }^{a *}$, A. Schneider ${ }^{b}$ and T. G. Oliveira \\ aUniversidade Federal do Pampa - UNIPAMPA, Rua Antonio Trilha, 1847, \\ Centro, CEP 97300-000, São Gabriel, RS, Brazil

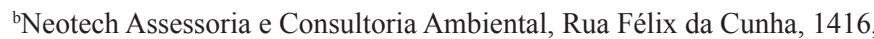 \\ apto 202. Centro, CEP 95800-000, Venâncio Aires, RS, Brazil \\ 'Instituto Pró-Carnivoros, Universidade Estadual do Maranhão - UEMA, Rua das Quaresmeiras, \\ casa 14, quadra 8, Jardim São Francisco, CEP 65076-270, São Luís, MA, Brazil \\ *e-mail: cbkasper@yahoo.com.br
}

Received: September 16, 2014 - Accepted: January 10, 2015 - Distributed: February 29, 2016

\begin{abstract}
Home range and minimal population densities of Southern tiger cat (Leopardus guttulus), margay (Lepardus wiedii) and jaguarundi (Puma yagouaroundi) were estimated between 2005 and 2006 in Taquari Valley, near the southern edge of the Atlantic Rainforest in Brazil. Home range data were collected by conventional radio telemetry (VHF) locations in a highly fragmented landscape. The average home range size, calculated using $95 \%$ kernel density estimates, was $16.01 \mathrm{~km}^{2}$ for Southern tiger cat, $21.85 \mathrm{~km}^{2}$ for margay and $51.45 \mathrm{~km}^{2}$ for jaguarundi. Telemetry data were used to obtain minimal density estimates of 0.08 Southern tiger cats $/ \mathrm{km}^{2}$, and 0.04 jaguarundi $/ \mathrm{km}^{2}$. The density estimates arise from areas where ocelot (Leopardus pardalis) and other larger-bodied carnivores were locally extinct, and they suggest a specific type of mesopredator release known as the ocelot effect, which is likely enabling the increase in smaller felid populations in this area.
\end{abstract}

Keywords: Leopardus guttulus, Leopardus wiedii, Puma yagouaroundi, telemetry, camera traps.

\section{Área de vida e densidade de três felídeos simpátricos na Mata Atlântica do Brasil}

\begin{abstract}
Resumo
Neste estudo são apresentadas áreas de vida e estimativas mínimas de densidade populacional do gato-do-mato-pequeno (Leopardus guttulus), gato-maracajá (Leopardus wiedii) e gato-mourisco (Puma yagouaroundi) obtidas entre 2005 e 2006, no Vale do Taquari, próximo ao limite sul da Mata Atlântica no Brasil. Os dados sobre área de vida foram coletados com a utilização de telemetria convencional (VHF) em uma paisagem altamente fragmentada. A área de vida média, calculada por Kernel $95 \%$, foi de $16,01 \mathrm{~km}^{2}$ para o gato- do-mato-pequeno, 21,85 $\mathrm{km}^{2}$ para o gato-maracajá e $51,45 \mathrm{~km}^{2}$ para o gato-mourisco. Os dados de telemetria foram utilizados para obter uma estimativa de densidade mínima de 0,08 gatos-do-mato-pequenos por $\mathrm{km}^{2}$, e 0,04 gatos-mourisco por $\mathrm{km}^{2}$. As estimativas de densidade são oriundas de áreas sem a presença de jaguatiricas (Leopardus pardalis) ou outros predadores de maior porte, todos localmente extintos, com possíveis efeitos de um tipo específico de relaxamento de mesopredadores, conhecido como "Efeito Pardalis" que podem permitir o aumento do tamanho das populações de gatos menores.
\end{abstract}

Palavras-chave: Leopardus guttulus, Leopardus wiedii, Puma yagouaroundi, telemetria, armadilhas fotográficas.

\section{Introduction}

Understanding population processes is fundamental for the development of conservation strategies (Caughley, 1977). Population density is a fundamental aspect of population ecology, yet it is often one of the least studied, especially for rare species. The study of felids presents an extreme example of this problem, since felids are usually found in low densities, are primarily nocturnal, shy and elusive (Karanth et al., 2003; Thomas and Miranda,

2003). Several researchers have been using camera traps for assessing demographic parameters such as density and abundance of elusive neotropical cats such jaguars (Panthera onca) (Linnaeus, 1758) (Wallace et al., 2003; Silver et al., 2004; Maffei et al., 2004; Soisalo and Cavalcanti, 2006; Paviolo et al., 2008) and ocelots (Leopardus pardalis) (Linnaeus, 1758) (Trolle and Kéry, 2003, 2005; Maffei et al., 2005; Di Bitetti et al., 2006, 2008; Dillon and 
Kelly, 2007; Maffei and Noss, 2008). Another technique available for investigating felid population densities is radio telemetry, which provides significant data on home range sizes, and individual use and selection of habitats, and enables better understanding of the spatial ecology of felid species. Again, just a limited numbers felid species in South America such jaguars (Crawshaw Junior and Quigley, 1991; Soisalo and Cavalcanti, 2006), mountain lions (Puma concolor) (Franklin et al., 1999; Mark et al., 2009), ocelots (Konecny, 1989; Dillon and Kelly, 2008) and Geoffroy's cat (Leopardus geoffroyi) (d'Orbigny \& Gervais, 1844) (Manfredi et al., 2006; Pereira, 2010) were subject of studies.

The ecology of smaller felids continues to be neglected in relation to other larger felid species such as jaguars, and population parameters remain unknown for most species. Recently, insights about the effect of the presence and density of ocelots over ecological parameters of smaller species were described, showing that Southern tiger cat (Leopardus guttulus) (Schreber, 1775), margay (Leopardus wiedii) (Schinz, 1821) and jaguarundi (Puma yagouaroundi) (É. Geoffroy, 1803) numbers are negatively affected by the presence of ocelot (Oliveira et al., 2010). However, data on the home range and densities of these small felids are scarce, limiting our understanding of ecological processes and requirements of these species. Ocelot densities are negatively affected by increased levels of human disturbance (Di Bitetti et al., 2008), which has been associated to the local extinction of the species in highly anthropized areas such as the Taquari Valley, in the southern limit of the Brazilian Atlantic Forest (Kasper et al., 2007). The absence of ocelot in some areas, including many locations within the fragmented Atlantic Forest, may provide opportunities for an increased abundance of smaller competing felid species.

Small felids such as the Southern tiger cat, margay and jaguarondi are poorly studied, and the knowledge about the spatial ecology and abundance of these species is hitherto limited. There is only one study that investigated the home range of jaguarundis in South America (Michalski et al., 2006), and few references about densities of Southern tiger cat populations through its distribution in Brazil (Tortato and Oliveira, 2005; Oliveira-Santos et al., 2012). Despite this dearth of information on the ecology of these species, they are classified as threatened by regional (Fontana et al., 2003) and national red lists (Oliveira et al., 2013; Tortato et al., 2013; Almeida et al., 2013).

The aim of this study is to estimate the home range size and the minimal densities for three small felid species, namely Southern tiger cat, margay and jaguarondi, in a fragmented area of southern Atlantic Forest, one of the most endangered biomes in the world.

\section{Material and Methods}

Telemetry studies were conducted in a fragmented area of the Taquari Valley, in the central region of Rio Grande do Sul State, southern Brazil (reference coordinate $\left.29^{\circ} 37^{\prime} \mathrm{S} 52^{\circ} 00^{\prime} \mathrm{W}\right)$. The study area is highly fragmented, and composed of a matrix of small properties (usually less than 10 ha), rice and soy crops, cattle ranching (which is the most important economic activity), and small native and exotic forest fragments. Almost all the households in the area hold small domestic stocks, which are mostly composed of chickens, and often represent the main source of conflict with the local fauna.

In this area, three Southern tiger cat, one margay and three jaguarundis were captured and fitted with VHF radio collars (Advanced Telemetry Systems, Model 1930). Captures were conducted using two to four Tomahawk traps $45 \times 60 \times 120 \mathrm{~cm}$ (width, height, length) baited with live domestic quails or chickens. Traps were placed in fragments and corridors of forest and set at 2 to $3 \mathrm{Km}$ apart. They were checked every morning, when food and water were provided for living baits. We relocated all traps each 30-40 days to increase trapping success and the possibility of capturing new individuals. Our total sample effort was 840 trap nights between October 2004 and December 2005.

Chemical immobilization was made by intramuscular administration of a combination of $10 \mathrm{mg} / \mathrm{kg}$ Ketamine and $2 \mathrm{mg} / \mathrm{kg}$ Xilazine (Dopalen and Anesaldan Vetbrands). Each animal was fitted with a VHF radio collar (Model 1930 Advanced Telemetry Systems). After recovery, all individuals were released at the capture site. All methods followed the guidelines of the American Society of Mammalogists (Gannon and Sikes, 2007).

Field data were collected 2 to 5 days a week until the end of VHF battery life or loss (mortality of individual or lack of signal) of a collared individual. Location data were collected by triangulation during daytime (White and Garrot, 1990) and opportunistically collected by the homing technique. Close to the estimated end of battery lifespan we conduct campaigns to recapture marked individuals and for collar removal. Only one individual was recaptured.

The location of animals was estimated using triangulations, which were implemented on LOAS (Ecological Software Solutions), discarding all locations with an error greater than 1 hectare. To calculate the home range area, we used all recorded locations of each individual using Minimum Convex Polygon (MCP) and 95\% kernel density estimates. The home range analyses were performed using Biotas 2.0 (Ecological Software Solutions). The overlap between individuals was estimated for those animals sharing contiguous areas that were simultaneously monitored. We calculated a minimum population density of the species by dividing the sum of the home range used for all individuals and the number of animals monitored.

\section{Results}

We collected 605 locations from seven individuals monitored for periods of 4 to 18 months. Jaguarundi showed the largest home ranges in this study, with an average of $51.45 \mathrm{~km}^{2}$ (95\% kernel-based home range), or $21.08 \mathrm{~km}^{2}$ (MCP). The $h$ parameter was wider in jaguarundi home ranges estimates (mean $h=856$ ), suggesting a movement 
Table 1. Home range of three Southern tiger cat (Leopardus guttulus), one margay (Leopardus wiedii), and three jaguarundi (Puma yagouaroundi) monitored in a fragmented landscape of southern Brazil.

\begin{tabular}{ccccc}
\hline Species & Id & Locations (period) & $\mathbf{1 0 0 \%}$ MCP & $\mathbf{9 5 \% ~ K e r n e l ~}$ \\
\hline \multirow{3}{*}{ Leopardus guttulus } & F1 & 149 (June 2005 to Oct. 2006) & $10.30 \mathrm{~km}^{2}$ & $16.42 \mathrm{~km}^{2}$ \\
\cline { 2 - 5 } & M1 & 148 (June 2005 to Dec. 2006) & $5.95 \mathrm{~km}^{2}$ & $11.18 \mathrm{~km}^{2}$ \\
\cline { 2 - 5 } & M2 & 34 (Aug. 2006 to Jan. 2007) & $5.28 \mathrm{~km}^{2}$ & $18.15 \mathrm{~km}^{2}$ \\
\hline Leopardus wiedii & F1 & 90 (Feb. 2006 to Oct. 2006) & $12.66 \mathrm{~km}^{2}$ & $21.85 \mathrm{~km}^{2}$ \\
\hline \multirow{3}{*}{ Puma yagouaroundi } & M1 & 114 (July 2005 to Nov. 2006) & $15.16 \mathrm{~km}^{2}$ & $30.44 \mathrm{~km}^{2}$ \\
\cline { 2 - 5 } & M2 & 34 (Apr. 2006 to Nov. 2006) & $17.41 \mathrm{~km}^{2}$ & $60.16 \mathrm{~km}^{2}$ \\
\cline { 2 - 5 } & M3 & 36 (Jan. 2006 to July 2006) & $30.68 \mathrm{~km}^{2}$ & $63.74 \mathrm{~km}^{2}$ \\
\hline
\end{tabular}

pattern more intense in comparison to the other two species in this study. Southern tiger cat, on other hand, showed smaller home range areas, with an average home range of $15.25 \mathrm{~km}^{2}$ (95\% kernel-based), or $7.18 \mathrm{~km}^{2}$ (MCP). The pattern of dispersion of locations for Southern tiger cat was more concentrated than those observed for jaguarundis, resulting in smaller $h$ parameter (average $h=503$ ). Margay presented an intermediary home range area with $21.85 \mathrm{~km}^{2}$ (95\% kernel-based, but with an $h$ parameter similar to that observed in Southern tiger cat $(\mathrm{h}=574)$. The MCP estimated $12.66 \mathrm{~km}^{2}$ as the home range for margay. Time of monitoring, number of locations and the home range of each individual is present in the Table 1.

We found three Southern tiger cats using a combined area of $37.22 \mathrm{~km}^{2}(100 \% \mathrm{MCP})$, resulting on a minimal density of 0.08 individuals $/ \mathrm{km}^{2}$. The same method was used to calculate jaguarundi density, which resulted on a combined area of $80.57 \mathrm{~km}^{2}$, and a minimal density of 0.04 individuals $/ \mathrm{km}^{2}$, based on data of three individuals.

\section{Discussion}

We present home range and minimal density estimates of three poorly known neotropical cats. Except for the jaguarundi, which occurs through Argentina, these species are studied in the southernmost region of their distribution, which provide an important foundation for future ecological comparisons with other areas where these species occur. Telemetry has become more frequently used over the past 30 years, motivated by miniaturization of devices and decrease of costs. However, only a few cat species have been studied so far, and almost nothing is known about the ecological requirements of these felids. Even basic ecological aspects, such as density estimates are lacking for many species. The use of home range to estimate densities provide secure estimates, given that the minimal numbers of individuals using an area is well known. This kind of analyses however, can underestimate real densities due to the existence of non-marked animals within the area of monitored individuals, therefore, we adopted the concept of minimal densities, which presents a conservative estimation that can be useful for conservation proposes.

The average home range of Southern tiger cat was smaller than the other two species, which is expected as Southern tiger cat is the smallest species of all the three cats in this study. However, the Southern tiger cat uses an average area of $21.85 \mathrm{~km}^{2}$ ( or $7.18 \mathrm{~km}^{2} \mathrm{MCP}$ ), a relatively large area for a cat with such a small body size (average of $3.00 \mathrm{~kg}$ ). For comparison, a larger cat like Geoffroy's cat, which weights up to $7.80 \mathrm{~kg}$, have home ranges varying between 2.48 to $3.42 \mathrm{~km}^{2}$ (MCP) in Argentina (Manfredi et al., 2006). Even ocelot, weighting 8-15 kg (Oliveira and Cassaro, 2005) presents smaller home ranges in locations such as Texas (Haines et al., 2006). Home range sizes can be affected by several ecological aspects such as, food availability, population density, resting sites, and other habitat characteristics; in this case, habitat fragmentation can be influencing the use of habitat and the size of home range for Southern tiger cat, as well as for other species. Jaguarundi seems to have larger home ranges than other small felids, as observed in other studies. In southeastern Brazil, jaguarundi uses areas ranging from 1.40 to $8.50 \mathrm{~km}^{2}$ (MCP) (Michalski et al., 2006), and 20 to $100 \mathrm{~km}^{2}$ in Belize (Konecny, 1989). In our study, jaguarundi uses areas of 15 to $30 \mathrm{~km}^{2}$ (MCP), or more than $60 \mathrm{~km}^{2}$ (95\% kernel). Such an increase on the home range estimates by kernel is due to the high degree of movement, and the consequent dispersion of locations.

The sympatric occurrence of three cat species is an indicative of a possible niche overlap. However, a parallel study using camera traps in the same region revels that $60 \%$ of the records of Southern tiger cat were taken in daytime hours, while all photographic records of margay were at night (personal communication). Telemetry records show a similar pattern, with considerable levels of "active" records during daytime for Southern tiger cat, while margay was generally inactive until sunset. This species can avoid competition by foraging at different times of the day (spatio-temporal avoidance). Similar results are cited by Oliveira-Santos et al. (2012), in a study that investigated the flexibility of the ecology of Southern tiger cat. Our data suggest that jaguarundis are much more active during the day, which could be increasing the potential of competition with Southern tiger cat.

Some researchers have been suggesting that population density of margays cannot be easily estimated because they show arboreal habits instead of traveling on the ground in comparison with other small cats. However, in our parallel study using camera traps, we recorded margay on the ground with relative frequency. Telemetry data of the unique individual monitored suggest the use of resting sites in trees during the day, which can explain several 
visualizations of this cat species in this arboreal behavior (most during day), commented by some researchers. During the night, the monitored margay traveled long distances in short periods (usually more than $1 \mathrm{~km}$ in less than 1 hour). These observations, in association with photographs of margay on the ground in several study sites (Di Bitetti et al., 2010; Vanderhoff et al., 2011; Oliveira-Santos et al., 2012), suggest that low abundance of for margay is not an artifact due to arboreal activities. Surmising that the capture rates of margay reflect the abundance of the species, we can estimate a density three times lower than Southern tiger cat and jaguarundis in our study site. In areas with the presence of ocelots, the density of small cats is minimal, as observed in Parque Estadual do Turvo, southern Brazil, where we found just one individual margay and one individual Southern tiger cat, in the same area used by 23 ocelots, over a three year period study (Kasper, 2007). This rarity of smaller cats in the presence of ocelots is congruent with other studies by Di Bitetti et al. (2010), Oliveira et al. (2010), and described in details by Oliveira et al. (2010) as a specific type of mesopredator release (Crooks and Soulé, 1999).

The minimal density estimates in this study are comparable with the lower limit of density estimation known for other small cats. In Bolivia, for instance, population density of Geoffroy's cat was estimated at 0.09-0.42 individuals $\mathrm{km}^{2}$ (Cuellar et al., 2006). Ocelot densities were estimated at 0.09-0.66 individuals $\mathrm{km}^{2}$ (Trolle and Kéry, 2003, 2005; Maffei et al., 2005; Dillon and Kelly, 2007) and in the Atlantic Forest specifically, estimates vary between 0.09-0.26 individuals $\mathrm{km}^{2}$ (Di Bitetti et al., 2006, 2008). Our estimate for Southern tiger cat is similar to those presented by Oliveira-Santos et al. (2012), but quite different from Tortato and Oliveira (2005), which present estimates of 0.87 individuals $/ \mathrm{km}^{2}$. We have no suggestion to explain this difference, but this seems to represent a pattern in which most of wild cats present low abundance, close to eight to ten individuals per $100 \mathrm{~km}^{2}$, using a conservative estimate.

In this study, we presented data of the use of fragmented areas by small felids. The use of this kind of landscape by species such Southern tiger cat and margay, suggest that conservation of some species is possible even in highly anthropized landscapes outside well-preserved areas. Conservation strategies that include fragmented areas exposed to human disturbance, especially in the Atlantic Forest can still play an important role on conserving threatened species of small, cats.

\section{Acknowledgements}

We are grateful to Fabio Dias Mazim and José Bonifácio Garcia Soares for helping and encourage our study. We also thank to Raquel von Hohendorff for helping us in the veterinary procedures. We are especially thankful to Allison Devlin and Leandro Abade for the critic review of the English language and content of this manuscript. Thanks MMA for the financial support to the project.

\section{References}

ALMEIDA, L.B., QUIEROLO, D., BEISIEGEL, B.M. and OLIVEIRA, T.G., 2013. Avaliação do risco de extinção do gatomourisco Puma yagouaroundi (É. Geoffroy Saint-Hilaire, 1803) no Brasil. Biodiversidade Brasileira, vol. 3, pp. 99-106.

CAUGHLEY, G., 1977. Analysis of vertebrate populations. New York: John Wiley \& Sons. 234 p.

CRAWSHAW JUNIOR, P.G. and QUIGLEY, H.B., 1991. Jaguar spacing, activity and habitat use in a seasonally flooded environment in Brazil. Journal of Zoology, vol. 223, no. 3, pp. 357-370. http://dx.doi.org/10.1111/j.1469-7998.1991.tb04770.x.

CROOKS, K.R. and SOULÉ, M.E., 1999. Mesopredator release and avifaunal extinctions in a fragmented system. Nature, vol. 400, no. 6744, pp. 563-566. http://dx.doi.org/10.1038/23028.

CUÉLLAR, E., MAFFEI, L., ARISPE, R. and NOSS, A.J., 2006. Geoffroy's cats at the northern limit of their range: activity patterns and density estimates from camera trapping in Bolivian dry forests. Studies on Neotropical Fauna and Environment, vol. 41, no. 3, pp. 169-178. http://dx.doi.org/10.1080/01650520600840001.

DI BITETTI, M.S., ANGELO, C.D., BLANCO, Y.D. and PAVIOLO, A., 2010. Niche partitioning and species coexistence in a Neotropical felid assemblage. Acta Oecologica, vol. 36, no. 4, pp. 403-412. http://dx.doi.org/10.1016/j.actao.2010.04.001.

DI BITETTI, M.S., PAVIOLO, A. and DE ANGELO, C., 2006. Density, habitat use and activity patterns of ocelots (Leopardus pardalis) in the Atlantic Forest of Misiones, Argentina. Journal of Zoology, vol. 270, no. 1, pp. 153-163.

DI BITETTI, M.S., PAVIOLO, A., DE ANGELO, C.D. and DI BLANCO, Y.E., 2008. Local and continental correlates of the abundance of a neotropical cat, the ocelot (Leopardus pardalis). Journal of Tropical Ecology, vol. 24, no. 02, pp. 189-200. http:// dx.doi.org/10.1017/S0266467408004847.

DILLON, A. and KELLY, M., 2007. Ocelot Leopardus pardalis in Belize: the impact of trap spacing and distance moved on density estimates. Oryx, vol. 41, no. 4, pp. 469-477. http://dx.doi. org/10.1017/S0030605307000518.

FONTANA, C.S., BENCKE, G.A. and REIS, R.E., 2003. Livro Vermelho da Fauna Ameaçada de Extinção no Rio Grande do Sul. Porto Alegre: Edipucrs. 632 p.

FRANKLIN, W.L., JOHNSON, W.E., SARNO, R.J. and IRIARTE, J.A., 1999. Ecology of the Patagonia puma Felis concolor patagonica in southern Chile. Biological Conservation, vol. 90, no. 1, pp. 33-40. http://dx.doi.org/10.1016/S0006-3207(99)00008-7.

GANNON, W.L. and SIKES, R.S., 2007. Guidelines of the American Society of Mammalogists for the use of wild mammals in research. Journal of Mammalogy, vol. 88, no. 3, pp. 809-823. http://dx.doi.org/10.1644/06-MAMM-F-185R1.1.

HAINES, A.M., GRASSMAN, L.I. Jr., TEWES, M.E. and JANECKA, J.E., 2006. First ocelot (Leopardus pardalis) monitored with GPS telemetry. European Journal of Wildlife Research, vol. 52, no. 3, pp. 216-218. http://dx.doi.org/10.1007/s10344-006-0043-5.

KARANTH, U., NICHOLS, J.D. and CULLEN, J.R.L., 2003. Armadilhamento fotográfico de grandes felinos: algumas considerações importantes. In: L. CULLEN JUNIOR, R. RUDRAN \& C. VALLADARES-PADUA, orgs. Métodos de estudo em biologia da conservação e manejo da vida silvestre. Curitiba: Editora UFPR, pp. 269-284. 
KASPER, C.B., 2007. Composição e abundância relativa dos mamíferos de médio e grande porte no Parque Estadual do Turvo, com ênfase em felinos. Porto Alegre: Universidade Federal do Rio Grande do Sul. 109 p. Dissertação em Biologia Animal.

KASPER, C.B., FELDENS, M.J., MAZIM, F.D., SCHNEIDER, A., CADEMARTORI, C.V. and GRILLO, H.C.Z., 2007. Mamíferos do Vale do Taquari, região central do Rio Grande do Sul. Biociencias, vol. 15, pp. 53-62.

KONECNY, M.J., 1989. Movement patterns and food habits of four sympatric carnivore species in Belize, Central America. In K. H. REDFORD and J. F. EISENBERG, eds. Advances in Neotropical Mammalogy. Gainesville: The Sandhill Crane Press, pp. 243-264.

MAFFEI, L., NOSS, A.J., CUÉLlAR, E. and RUMIZ, D.I., 2005. Ocelot (Felis pardalis) population densities, activity, and ranging behavior in the dry forests of eastern Bolivia: data from camera trapping. Journal of Tropical Ecology, vol. 21, no. 3, pp. 1-6. http://dx.doi.org/10.1017/S0266467405002397.

MANFREDI, C., SOLER, L., LUCHERINI, M. and CASANAVE, E.B., 2006. Home range and habitat use by Geoffroy's cat (Oncifelis geoffroyi) in a wet grassland in Argentina. Journal of Zoology, vol. 268 , no. 4 , pp. 381-387. http://dx.doi.org/10.1111/j.14697998.2005.00033.x.

MARK, E., HEIKO, U.W., SAUCEDO, C. and CORTI, P., 2009. Long-distance dispersal of a male puma (Puma concolor) in Patagonia. Revista Chilena de Historia Natural (Valparaiso, Chile), vol. 82, pp. 459-461.

MICHALSKI, F., CRAWSHAW, P.G., OLIVEIRA, T.G. and FABIAN, M.E., 2006. Notes on home range and habitat use of three small carnivore species in a disturbed vegetation mosaic of southeastern Brazil. Mammalia, vol. 70, no. 1-2, pp. 52-57. http://dx.doi.org/10.1515/MAMM.2006.004.

OLIVEIRA, T.G. and CASSARO, K., 2005. Guia de campo dos felinos do Brasil. São Paulo: Instituto Pró Carnivoros/ Fundação Parque Zoologico de São Paulo/Sociedade de Zoologicos do Brasil/Pró-Vida Brasil. 80 p.

OLIVEIRA, T.G., TORTATO, M.A., ALMEIDA, L.B., CAMPOS, C.B. and BEISIEGEL, B.M., 2013. Avaliação do risco de extinção do gato-do-mato Leopardus tigrinus no Brasil. Biodiversidade Brasileira, vol. 3, pp. 56-65.

OLIVEIRA, T.G., TORTATO, M.A., SILVEIRA, L., KASPER, C.B., MAZIM, F.D., LUCHERINI, M., JACOMO, A.T., SOARES, J.B.G., MARQUES, R.V. and SUNQUIST, M., 2010. Ocelot ecology and its effect on the small-felid guild in the lowland neotropics.
In: D. MACDONALD and A. LOVERIDGE, orgs. Biology and conservation of wild felids. Oxford: Oxford University Press.

OLIVEIRA-SANTOS, L.G., GRAIPEL, M.E., TORTATO, M.A., ZUCCO, C.A., CÁCERES, N.C. and GOULART, F.V.B., 2012. Abundance changes and activity flexebility of the oncilla, Leopardus guttulus (Carnivora: Felidae), appear to reflect avoidance of conflict. Zoologia, vol. 29, no. 2, pp. 115-120.

PEREIRA, J.A., 2010. Activity pattern of Geoffroy's cats (Leopardus geoffroyi) during a period of food shortage. Journal of Arid Environments, vol. 74, no. 9, pp. 1106-1109. http://dx.doi. org/10.1016/j.jaridenv.2010.03.017.

SOISALO, M.K. and CAVALCANTI, S.M.C., 2006. Estimating the density of a jaguar population in the Brasilian Pantanal using camera-traps and capture-recapture sampling in combination with GPS radio-telemetry. Biological Conservation, vol. 129, no. 4, pp. 487-496. http://dx.doi.org/10.1016/j.biocon.2005.11.023.

THOMAS, W.M. and MIRANDA, G.H.B., 2003. Uso de armadilhas fotográficas em levantamentos populacionais. In: L. CULLEN JUNIOR, R. RUDRAN and C. VALLADARES-PADUA, orgs. Métodos de estudo em biologia da conservação e manejo da vida silvestre. Curitiba: Editora UFPR, pp. 243-267.

TORTATO, M.A. and OLIVEIRA, T.G., 2005. Ecology of oncilla (Leopardus tigrinus) at Serra do Tabuleiro State Park, Southern Brazil. Cat News, vol. 42, pp. 28-30.

TORTATO, M.A., OLIVEIRA, T.G., ALMEIDA, L.B. and BEISIEGEL, B.M., 2013. Avaliação do risco de extinção do gato-maracajá Leopardus wiedii (Schinz, 1821) no Brasil. Biodiversidade Brasileira, vol. 3, pp. 76-83.

TROLLE, M. and KÉRY, M., 2003. Estimation of ocelot density in the pantanal using capture-recapture analysis of camera-trapping data. Journal of Mammalogy, vol. 84, no. 2, pp. 607-614. http:// dx.doi.org/10.1644/1545-1542(2003)084<0607:EOODIT>2.0.CO;2.

TROLLE, M. and KÉRY, M., 2005. Camera-trap study of oceolot and other secretive mammals in northern Pantanal. Mammalia, vol. 69, no. 3-4, pp. 405-412. http://dx.doi.org/10.1515/mamm.2005.032.

VANDERHOFF, E.N., HODGE, A.M., ARBOGAST, B.S., NILSSON, J. and KNOWLES, T.W., 2011. Abundance and activity patterns of the margay (Leopardus wiedii) at a mid-elevation site in eastern Andes of Ecuador. Mastozoología Neotropical, vol. 18 , no. 2 , pp. 271-279.

WHITE, G.C. and GARROT, R.A., 1990. Analysis of wild-life radio-tracking data. San Diego: Academic Press. 